\section{*Şevket ALP}

Orcid No: 0000-0002-9552-4848

**Nurbanu KAFADAR

Orcid No: 0000-0002-6747-6498

***Faruk ÇELİKEL

Orcid No: 0000-0002-2701-3544

*Van Yüzüncü Y1l Üniversitesi, Mimarlık ve Tasarım Fakültesi, Peyzaj Mimarlığı Bölümü (Sorumlu yazar)

**Siirt Üniversitesi, Tasarım Meslek Yüksekokulu, Bilgisayar Destekli Tasarım ve Animasyon Programı ***Spor Antrenörü, İstanbul

DOI

https://doi.org/10.46291/ISPECJASv ol4iss4pp1022-1034

Geliş Tarihi: 26/10/2020

Kabul Tarihi: 29/11/2020

\section{Anahtar Kelimeler \\ Açık yeşil alan, fitness aletleri, fiziksel aktivite, kilo kontrolü}

\section{Keywords}

Open green area, fitness equipment, physical activity, weight control

\section{İstanbul'da Açık Yeşil Alanlarda Kurulan Dış Mekân Spor Aletlerinin Kullanımı Ve Beklentilerin Değerlendirilmesi}

\section{Özet}

Bu çalışma, İstanbul Büyükşehir Belediyesi sınırları içinde yer alan ve diş mekân spor aletlerinin yerleştirildiği; Beylikdüzü, Gürpınar, Çamlıca, Emirgan, Maçka ve Yıldız Parkları'nda yürütülmüştür. Bu alanları kullanan bireylerin profillerini belirlemek, aletlerle ilgili katılım ve beklentileri incelemek amacıyla anket çalışması yapılmıştır. Ankette; demografik yapı, egzersiz alanı ve egzersiz aletlerinin kullanımı olmak üzere üç başlık altında toplamda 41 soru sorulmuştur. Açık yeşil alanlarda yer alan dış mekân spor aletlerinden bireylerin yararlandiğı ve memnun oldukları görülmektedir. Ankete katılan halkın \%72 si bu uygulamadan memnun iken, \% 28'i memnun olmadığını belirtmiştir. En fazla memnuniyet \%76 ile Beylikdüzün'de iken, en az memnuniyet \% 34 ile Emirgan'da tespit edilmiştir. Belediyeye ait açık yeşil alanlarda kurulan bu aletleri kullanıcıların; kilo verme ya da kilosunu kontrol altında tutma, fiziksel görünüşünü iyileştirme ve sosyal imajını geliştirmek gibi dış görünüşe yönelik nedenlerden ötürü kullandıkları tespit edilmiştir. Kişilerin ruhsal ve fiziksel sağlığına katkıda bulunan bu etkinliklerden beklenen faydanın sağlanması için bir takım önlemlerin alınması gerekmektedir. Bu önlemler alındığında, mevcut açık yeşil alanlardaki spor aletlerinin daha doğru ve etkin bir şekilde kullanımı sağlanacaktır. Etkin ve verimli kullanılan açık yeşil alanlarının toplum sağlığına katkısı yanında insanların serbest zamanlarını daha verimli kullanımlarına da katkısı olacaktır.

\section{Use of Outdoor Sports Equipment Set Up in Open Green Areas in Istanbul and Evaluation of Expectations}

\section{Abstract}

This study is located within the Istanbul Metropolitan Municipality and where outdoor sports equipment are placed; He conducted it in Beylikdüzü, Gürpınar, Çamlıca, Emirgan, Maçka and Yıldız Parks. A questionnaire was conducted in order to determine the profiles of the individuals using these areas and to examine the participation and expectations about the exercise equipment. In the survey; A total of 41 questions were asked under three headings: demographic structure, exercise area, and use of exercise equipment. It is seen that individuals benefit from the outdoor sports equipment in open green areas and are satisfied. While $72 \%$ of the people participating in the survey are satisfied with this application, $28 \%$ of them stated that they are not. While the highest satisfaction was in Beylikdüzün with $76 \%$, the least satisfaction was found in Emirgan with 34\%. These exercise equipment installed in the open green areas belonging to the municipality; It has been found that they use it for external appearance reasons such as losing weight or keeping it under control, improving their physical appearance and improving their social image. A number of measures should be taken to ensure the expected benefit from these activities that contribute to the mental and physical health of people. When these measures are taken, more accurate and efficient use of sports equipment in existing open green areas will be ensured. Open green spaces that are used effectively and efficiently will contribute to the public health as well as the more efficient use of people's leisure time. 


\section{GíRIŞ}

Toplumun birbirlerinden başkalaşan kesimleri için bir buluşma alanı rolü üstlenen kentler, bireyleri bir arada tutan ve her kesimden insanı kaynaştıran, sosyalleştiren mekanlardır. Özellikle kamusal alanlar (sivil ve resmi kamusal alanlar) kentlerin oluşumu sürecinde önemli bir noktada yer almaktadır. Birey, sosyokültürel yaşantısını, kentsel dış mekanlardaki yaşantı ve aktiviteler ile sürdürmektedir (Erdönmez ve Ak1, 2005). $\mathrm{Bu}$ anlamda, toplumun yapilanmasi, bireyler ve toplum arasındaki ilişkinin çevre tarafından desteklendiği mekan olan açık kamusal alanlarda oluşmaktadır. $\mathrm{Bu}$ mekanların en önemli fonksiyonu yapıların arasında sosyal doku oluşturmaktır. Kentleşme toplum ve bireyleri için sosyal ve kültürel yararlar sunsa da suni ve sağlıksız bir çevrede yaşama zorunluluğu da oluşturmaktadır. Ülkemizde 1950 yıllarda başlamış ve hızlı bir süreç olarak işleyen bu durum, ekolojik dengenin de hızlıca sağlıksız duruma gelmesine sebep olmuştur. Bu süreçteki yetersiz ve yanlış çevre politikaları, sosyal ve ekonomik problemler; sürdürülebilir olmayan yapılaşmaya, arazinin yasal olmayan işgaline ve çevre koruma çalışmalarındaki aksamaya sebep olarak dolayısıyla yeşil alanların kaybına neden olmaktadır (Melchert, 2005; Önder ve Polat, 2012). Gül ve Küçük (2001)' e göre; kent içerisinde mimari yapı ve açık-yeşil alanların birbiriyle olan ilişkisi ve bütünlüğü o kentin genel karakterini ortaya koymaktadır. Açık-yeşil alanlar, birey ile doğa arasındaki bozulan dengeyi ve kent yaşamının koşullarını iyileştirmeyi hedeflemektedir. Gelişmiş ülkelerde açıkyeşil alanların nitelik ve nicelikleri, medeniyetin ve yaşam kalitesinin bir göstergesi olarak kabul edilmektedir. $\mathrm{Bu}$ nedenle gelişmiş ülkeler, bireylerin mental ve fiziksel gereksinimlerini önemseyerek kent mekanını ve ekoloji konularını birleştirerek planlama çalışmalarına yönelmektedirler. Örneğin, İsveç, Norveç ve Finlandiya ülkelerinde, tüm doğa alanları kamusal alan olarak kabul edilmiş ve halkın ortak geçiş hakkı olarak tanımlanmıştır. Buna karşın ülkemizde böyle bir yasa boyutuna bile gelememenin dişında; yerleşim alanlarında, yeşil alanların yetersiz olduğu, bu durumun kent halkının rekreasyon ve park kullanımını olumsuz yönde etkilediği yönünde gözlemler bulunmaktadır (Çerçi, 2012). Bireyler sosyo-kültürel, ekonomi gibi durumlarına göre farklılık gösterse de fiziksel gelişim, yenilik arayışı, değişik deneyimler edinme, 
kendini sınama ve geliştirme, yaratıcı olma, sosyalleşme ihtiyacı, dinlenme veya rahatlama ihtiyac1, yarışma güdüsünü tatmin, sağlık gibi gerekçelerle bireyler rekreatif etkinliklere katılmaktadırlar. $\mathrm{Bu}$ etkinlikleri zamana, mekana bağlı olarak aktif veya pasif katılım, iç veya dış mekanda yapılmasına göre sınıflandırmak mümkündür (Ardahan ve Yerlisu Lapa, 2011). Rekreatif etkinliklerin, toplumun parçasını oluşturan bireylerin bir araya gelerek sosyal ilişkiler kurmasında önemli rolü olmakla beraber insanların beceri, yetenek ve yaratıcılık gücünün, ortaya çıkmasına ve geliştirilmesine hizmet etmesi gerektiği düşünülmektedir. Kentleşmenin yoğunlaştığı bu dönemlerde açık yeşil alanların kentin nefes alma bölgeleri olarak görülmesi sebebiyle sorumlulukları ve gereklilikleri artmaktadır (Koçan, 2007). Kentin fiziki ve ruhsal baskınlığından kaçabilmenin yolu genellikle fiziksel aktivitenin artrilmasiyla bağdaştırılmaktadır. Fiziksel aktivite açık alanlarda yapıldığında kapalı alanlara oranla daha sağlıklı ve verimli olduğu bilinmektedir. Bireylerin bu talebini karşılayabilmek amacıyla planlı, amacına uygun ve estetiği de göz önünde bulunduran bir çalışmayla yeşil alanların, oyun ve spor alanlarının peyzaj düzenlemeleri gerekli olmaktadır. Bireylerin rekreasyona katılımlarına yönelik artan ihtiyaçlarının giderilmesinde kurum ve kuruluşların üzerlerine düşen görevleri yerine getirmesi gerekmektedir. Rekreasyon faaliyetlerine katılanların en çok yararlandığı alanlardan biri de parklardır. Büyükşehir ve ilçe belediyeleri, Park ve Bahçeler Müdürlüğü altında 5393 sayılı Belediye kanununun ve ilgili mevzuat kanunlarına dayanılarak hazırlanan Park ve Bahçeler Müdürlüğü Görev ve Çalışma Yönetmeliği kapsamında; İl/İlçe sınırlarında yetişkinlerin, gençlerin ve çocukların rekreatif faaliyetlerine hizmet etmesi amacı ile parklar dahilinde yürüyüş yolları, bisiklet yolları, spor alanları, yeşil alanlar tesis etmek ve bunların bakım, onarım ve iyileştirme çalışmalarını yapmaktadır. Belediyelerin inşa ettiği bu parklar içerisinde yer alan yürüyüş ve bisiklet yollarından, fitness aletlerinden bireylerin yoğun bir şekilde yararlanıldığ görülmektedir (Karaküçük, 1995; Yerlisu Lapa ve ark., 2012). $\mathrm{Bu}$ alanların planlanmasında ve tasarlanmasında ilgili kurumların, kullanıcıların ilgi ve eğilimlerini belirlemeye yönelik çalışmalar yapmak, cinsiyet, yaş, gelir, kalıtım, eğitim süreci gibi faktörleri rekreasyon programı yaparken göz önünde bulundurulması 
gerekmektedir. İstanbul'da ise bireylerin rekreatif gereksinimleri uzun yılar ihmal edilmiş olup, bu durum günümüzde de devam etmektedir. Bu durum mevcut açık rekreasyon alanlarının kalitesini düşürmekte, bireylerin rekreasyon tercihlerini sinırlandırmakta ve rekreasyon aktivitelerine katılımını olumsuz olarak etkilemektedir.

\section{MATERYAL ve YÖNTEM}

Araştırmanın materyalini İstanbul Büyükşehir Belediyesi sınırları içinde yer alan ve dış mekan spor aletlerinin yerleştirildiği; Beylikdüzü, Bakırköy, Çamlıca, Emirgan, Maçka ve Yıldız parklarında her bir parkta rastgele seçilen 50 kişi oluşturmaktadır. Araştırma, açık yeşil alanlarda kurulan dış mekan spor aletlerini kullanan bireylerin demografik özelliklerini ve bu sporu yaparken çevreleriyle olan etkileşimini ve beklentilerini belirlemeye yönelik betimsel ve tanımlayıcı bir çalışma niteliğindedir.

\section{ARAŞTIRMA BULGULARI}

Ankette; demografik yap1, egzersiz alanı ve egzersiz aletlerinin kullanımı olmak üzere üç başlık altında toplamda 41 soru sorulmuştur. Ankete katılan bireylerin; $\% 51$ 'i erkek, \%49'u ise kadın kullanıcılardan oluşmaktadır. Bütün bölgelerde ortalama yaşın 29 ile 31 yaş aralığında olduğu, minimum ve maksimum yaş değerine bakıldığında ise 10 yaşında ve 63 yaşında katılımcı bireylerin olduğu görülmektedir. İlkokul mezunlarının oranı $\% 15$ iken, üniversite mezunlarının oranı \%43 düzeyinde olduğu tespit edilmiştir. Bireyler ortalama olarak 2000-3000 TL (\%34) ve 1000-2000 TL (\%32) düzeyde gelire sahiptir. Katılımcıların aletleri ve alanı genellikle sabah saatlerinde (\%56), haftada 2-3 gün $(\% 40)$ ve yılın her dönemi (\%44) kullanmayı tercih ettiği anlaşılmaktadır. Araştırmaya katılan bireylerin egzersiz aletleri ile ilgili sorulara verdikleri cevaplar Çizelge 1'de görülmektedir. Çizelge 1'den da anlaşılacağı üzere alanlarda kullanılan aletlerin sağlam ve kullanışılı olduğu, özel alanlarda en sik kullanılan aletlere benzer aletlerin varlığı ve yürüyüş alanlarıyla yakın olması sebebiyle entegre olarak kullanılabileceği görülmektedir. Aletlerin doğru amaçla kullanıldığını düşünenlerin oranı \%30'dur ancak bu soruya bilmiyorum cevab1 veren bireylerin oran 1 ise $\% 45$ olarak hesaplanmıştır. 
Çizelge 1. Egzersiz aletlerinin kullanımına yönelik veriler

\begin{tabular}{|l|l|l|}
\hline Egzersiz aletlerini kulanmalarından kaynaklanan sakatık durumu & Kişi sayısı & Değer (\%) \\
\hline Evet & 58 & 10 \\
\hline Hayır & 242 & 90 \\
\hline Egzersiz aletlerinin sağlamlık ve kullanışııı̆̆ı & Kişi sayısı & Değer (\%) \\
\hline Evet & 196 & 70 \\
\hline Hayır & 104 & 30 \\
\hline $\begin{array}{l}\text { Özel spor salonlarıda en çok kullanılan koşu bandı ve serbest ağırlıkların } \\
\text { egzersiz alanlarında kullanılabilirliği }\end{array}$ & Kişi sayısı & Değer (\%) \\
\hline Evet & 192 & 52 \\
\hline Hayır & 108 & 48 \\
\hline Egzersiz aletlerinin yürüyüş alanlarına olan mesafesi & Kişi sayısı & Değer (\%) \\
\hline Yakın & 186 & 78 \\
\hline Uzak & 114 & 22 \\
\hline Egzersiz aletlerinin amacına uygun kullanımı & Kişi sayısı & Değer (\%) \\
\hline Evet & 90 & 30 \\
\hline Hayır & 75 & 25 \\
\hline Bilmiyorum & 135 & 45 \\
\hline
\end{tabular}

Çizelge 2. Alanda bulunan egzersiz aletlerine yönelik veriler

\begin{tabular}{|l|l|l|}
\hline İstedikleri tüm egzersiz aletlerinin alanda bulunması & Kişi sayısı & Değer (\%) \\
\hline Evet & 129 & 46 \\
\hline Hayır & 171 & 54 \\
\hline $\begin{array}{l}\text { Egzersiz alanlarının zayıflamak veya çok zayıf bireylerin kilo alması } \\
\text { ihtiyacını karşı̇lama }\end{array}$ & Kişi sayısı & Değer (\%) \\
\hline İhtiyacı Karşılıyor & 190 & 60 \\
\hline İhtiyacı Karşılamıyor & 110 & 40 \\
\hline Egzersiz alanlarının uzaklığı & Kişi sayısı & Değer (\%) \\
\hline Uzak & 166 & 66 \\
\hline Yakın & 134 & 34 \\
\hline Egzersiz alanlarına gelmek için kullandıkları ulaşım aracı & Kişi sayısı & Değer (\%) \\
\hline Bisiklet ile & 64 & 21 \\
\hline Yürüyerek & 149 & 50 \\
\hline Motorlu araçlar ile & 87 & 29 \\
\hline
\end{tabular}

Araştırmaya katılan bireylerin alandaki egzersiz aletlerine dair sorulara verdikleri cevaplar Çizelge 2'de görülmektedir. Alanın içerisinde bulunan aletlerin yetersiz olduğunu düşünen (\%54) kullanıcılar, var olan aletlerin zayıflama ya da kilo alma ihtiyacını karşıladığını \%60 oranla düşünmektedir. Çizelge 2'ye göre; her iki kullanıcıdan biri uzak olarak tanımladıkları bu alanlara yürüyerek ulaşmaktadırlar (\%66). $\mathrm{Bu}$ Çizelgenin dışında verileri incelenen bazı soruların cevapları ve yüzde oranlarına göre; egzersiz alanlarında bulunan ekipmanlarda sağlık problemi olan bireylerin alanı kullanmaması konusunda uyarılar olmadığını belirtenler $\% 87$ ile büyük bir oranı teşkil etmektedir. Katılımcıların \%88'lik oranı egzersiz 
aletlerini doğru kullanmalarına yardımcı olacak olan yetkililerin olmadı̆̆ı; \%68'lik oran ise bu konuda uzman bireylerin olması gerektiğini düşünmektedir. Araştırmaya katılan bireylerin egzersiz alanlarını neden kullandıklarına yönelik verilerde; en fazla vurgulanan ifadenin \%46,0 ile sağlıklı yaşam amacı olduğu görülmektedir.

Çizelge 3. Egzersiz alanındaki yardımcı alanlar ile ilgili veriler

\begin{tabular}{|l|l|l|}
\hline $\begin{array}{l}\text { Egzersiz alanlarını kullandıkları sırada araçlarını park etmek için alanda } \\
\text { otopark bulunması }\end{array}$ & Kişi sayısı & Değer (\%) \\
\hline Var & 102 & 37 \\
\hline Yok & 198 & 63 \\
\hline Egzersiz alanlarını kullandıkları sırada su ihtiyacını giderme durumu & Kişi sayısı & Değer (\%) \\
\hline Evet & 140 & 30 \\
\hline Hayır & 160 & 70 \\
\hline Egzersiz alanlarını kullandıkları sırada tuvalet ihtiyacını giderme durumu & Kişi sayısı & Değer (\%) \\
\hline Evet & 124 & 39 \\
\hline Hayır & 176 & 61 \\
\hline $\begin{array}{l}\text { Egzersiz alanlarını kullandıkları sırada soyunma kabini ihtiyacını } \\
\text { giderme durumu }\end{array}$ & Kişi sayısı & Değer (\%) \\
\hline Evet & 69 & 14 \\
\hline Hayır & 231 & 86 \\
\hline $\begin{array}{l}\text { Alanda egzersiz öncesi ve sonrası dinlenmek için oturma yerlerinin } \\
\text { ihtiyacı giderme }\end{array}$ & Kişi sayısı & Değer (\%) \\
\hline Evet & 208 & 69 \\
\hline Hayır & 92 & 31 \\
\hline
\end{tabular}

Çizelge 3'de bireylerin alanı kullanırken ihtiyaç duyabileceği bazı mekanların varlığına ve yeterliliğine dair veriler bulunmaktadır. $\mathrm{Bu}$ verilere bakıldığında otopark, tuvalet, soyunma kabini gibi mekanların çoğunlukla bulunmadığ 1 anlaşılmaktadır. Bunların yanında oturma ve dinlenme amaçlı yerlerin \%69 oranla var olduğu görülmektedir.

Çizelge 4. Alandaki bitkilendirmeye yönelik veriler

\begin{tabular}{|l|l|l|}
\hline Alanın bitkilendirilmesi & Kişi sayısı & Değer (\%) \\
\hline Çok önemli & 183 & 61 \\
\hline Az önemli & 60 & 20 \\
\hline Önemsiz & 57 & 19 \\
\hline Alanda hangi bitkilerin olmasına yönelik & Kişi sayısı & Değer (\%) \\
\hline Çim & 42 & 14 \\
\hline Çiçekli Bitkiler & 46 & 15 \\
\hline Kokulu Bitkiler & 51 & 17 \\
\hline Gölge Yapan Ağaçlar & 54 & 18 \\
\hline Hepsi & 107 & 36 \\
\hline Alanın güneşli veya gölgelik olma durumu & Kişi sayısı & Değer (\%) \\
\hline Güneşli & 220 & 73 \\
\hline Gölgelik & 80 & 27 \\
\hline
\end{tabular}


Çizelge 4'de görüldüğü üzere kullanıcılar spor yapılan alanlarda bitkilendirmenin çok önemli olduğunu (\%61) ve bu bitkilendirmenin farklı türlerde bitkilerden oluşması gerektiğini düşünmektedirler. Alanı kullanan bireyler çoğunlukla spor yaparken güneşli olması durumunu tercih etmektedir.

Çizelge 5. Alanın bireyler üzerindeki etkilerine yönelik veriler

\begin{tabular}{|l|l|l|}
\hline Egzersiz aletlerinin bulunduğu alanın ilk dikkat çeken özelliği & Kişi sayısı & Değer (\%) \\
\hline Bitki & 66 & 22 \\
\hline Mimari & 62 & 21 \\
\hline Doğallık & 91 & 30 \\
\hline Alet çeşitliliği & 81 & 27 \\
\hline Alanın estetik özelliği & Kişi sayısı & Değer (\%) \\
\hline Çok iyi & 52 & 19 \\
\hline lyi & 103 & 34 \\
\hline Orta & 95 & 32 \\
\hline Kötü & 45 & 15 \\
\hline Alanın bireyde oluşturduğu psikolojik izlenimi & Kişi sayısı & Değer (\%) \\
\hline Dinlendirici & 81 & 27 \\
\hline Yorucu & 86 & 29 \\
\hline Fikrim Yok & 133 & 44 \\
\hline
\end{tabular}

Çizelge 5'de alanın bireyler üzerinde bıraktığ1 etkilere yönelik veriler bulunmaktadır. Kullanıcılar alanlarda en çok dikkat çeken varlığın genellikle doğallık (\%30) olduğunu belirtmektedirler. Ancak alet çeşitliliğinin (\%27) de doğallık kadar alanlarda dikkat çekici olduğu görülmektedir. Kullanıcılar alanları iyi ve orta derecede estetik bulmaktadır. Psikolojik olarak alanın değerlendirilmesi istendiğinde 100 kişide 44 kişi bu konuda fikri olmadığını, 29 kişi yorucu olduğunu ve 27 kişi ise dinlendirici etkiye sahip olduğunu düşünmektedir.

Çizelge 6. Alanın zemin durumuna ait veriler

\begin{tabular}{|l|l|l|}
\hline Egzersiz alanlarının zemin durumu & Kişi sayısı & Değer (\%) \\
\hline Beton & 50 & 17 \\
\hline Kauçuk & 50 & 17 \\
\hline Lastik & 100 & 33 \\
\hline Kilit Taşı & 100 & 50 \\
\hline Egzersiz alanlarının zemininin çalışmayı olumsuz etkileme & Kişi sayısı & Değer (\%) \\
\hline Evet & 91 & 30 \\
\hline Hayır & 209 & 70 \\
\hline
\end{tabular}


Çizelge 6'da görüldüğü üzere alanlara ait yapısal verler bulunmaktadır. Alanlar genel olarak kilit taşından oluşmakta ve bu durum çalışmayı olumsuz etkilememektedir.

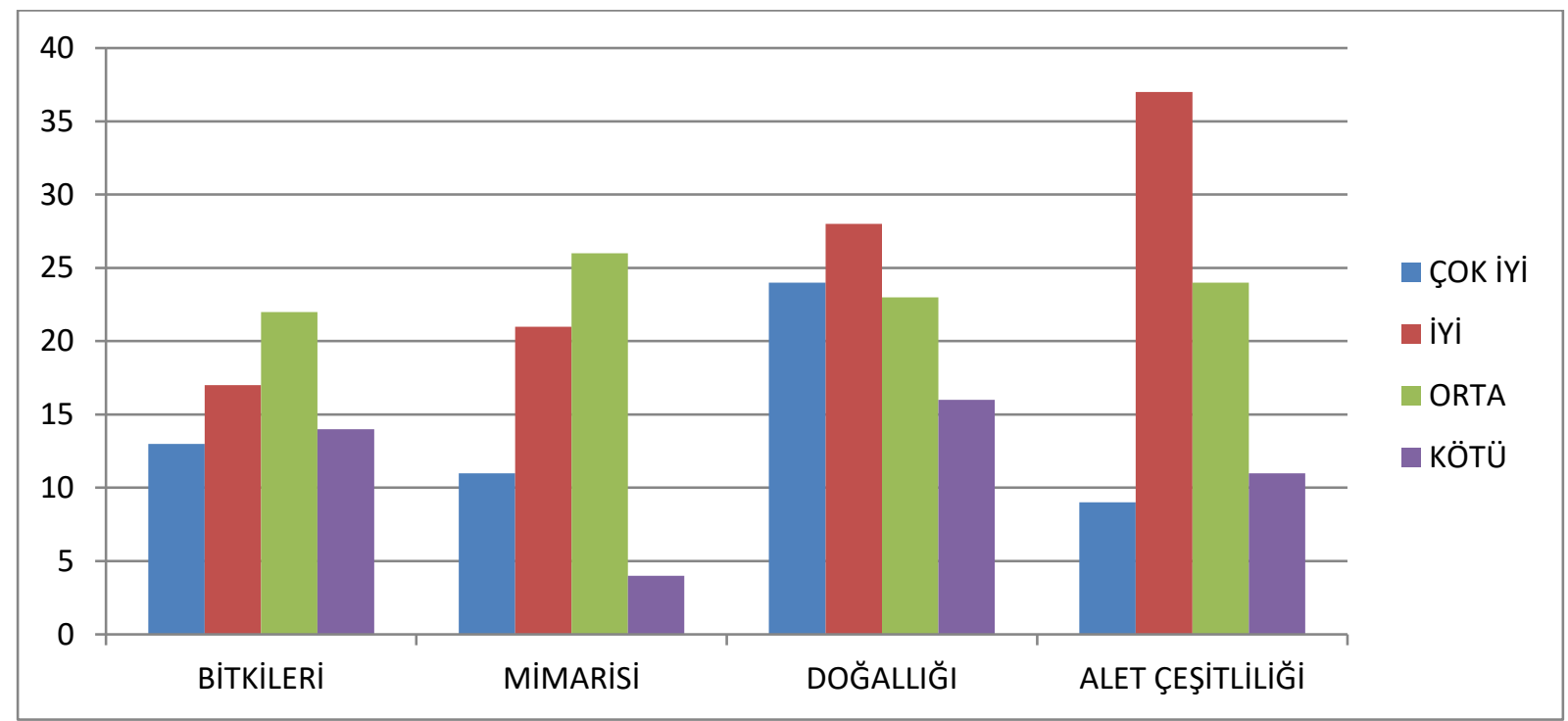

Şekil 1. Katılımcıların egzersiz yapılan alanda ilk dikkat çeken özellik ile bu alanların estetik açıdan değerlendirilmesi arasındaki ilişki durumuna göre yapılan analiz sonuçları

Katılımciların egzersiz yapılan alanın ilk dikkat çeken özelliği ile bu alanların estetik açıdan değerlendirilmesi arasındaki ilişkiye bakıldığında Şekil 1'de görüldüğü üzere; alet çeşitliliğinin genel olarak iyi olarak tanımlandığı ve tüm özelliklere bakıldığında ise parkların estetik anlamda tüm ögeler açısından orta olarak değerlendirildiği gözlemlenmektedir. Katılımcıların egzersiz yapılan alanda ilk dikkat çeken özelliği ile bu alanlarda hangi bitklerin olmasının istendiği arasındaki ilişski durumuna göre yapılan analiz sonuçlarına bakıldığında; alet çeşitliliğinin ilk dikkat çeken öge olduğu noktalarda çim, çiçekli bitkiler, kokulu bitkiler ve gölge yapan ağaçların bir arada bulunduğu bitki gruplarının daha fazla tercih edildiği görülmektedir. 


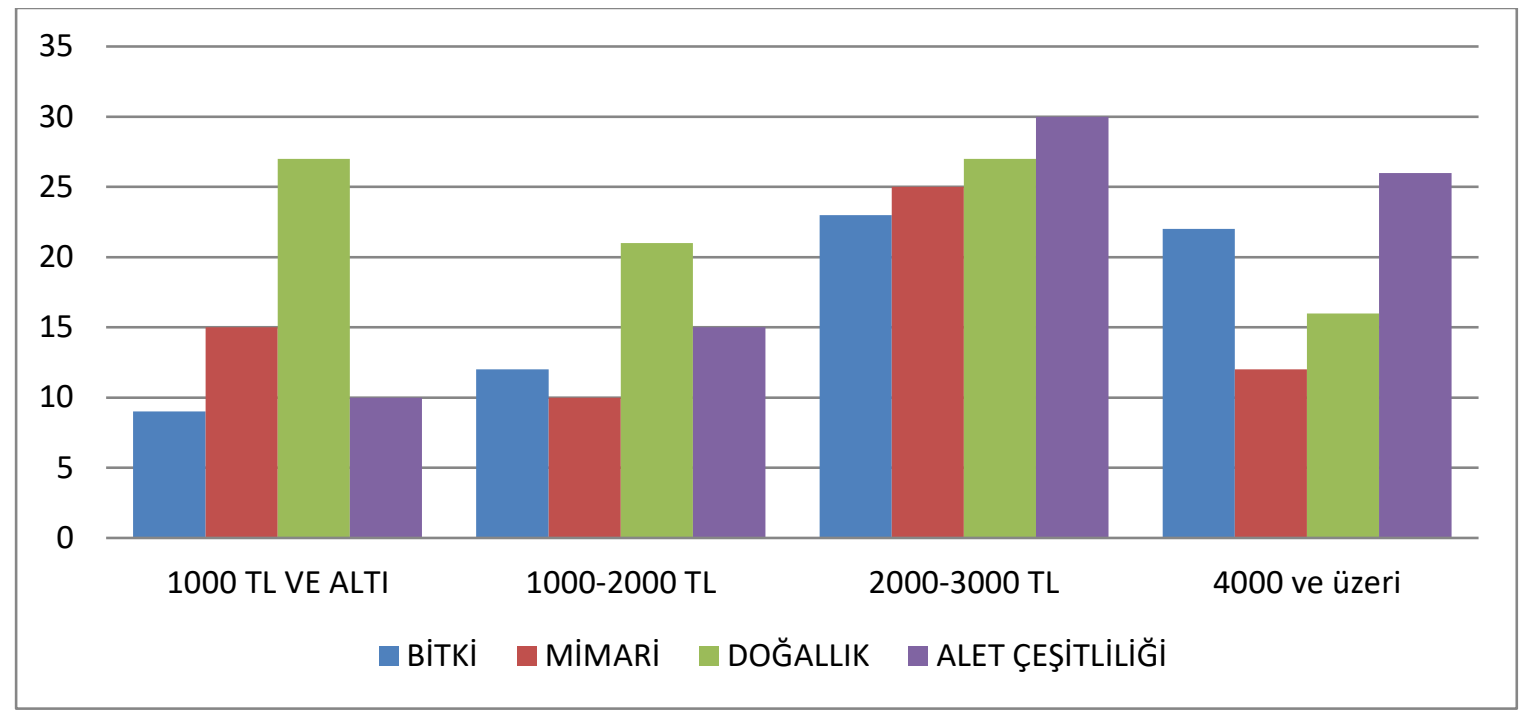

Şekil 2. Katılımcıların gelir düzeyleri ile egzersiz yapılan alanda ilk dikkat çeken özellik arasındaki ilişki durumuna göre yapılan analiz sonuçları

Katılımcı bireylerin ortalama gelir düzeyi analizine baktığımızda 2000-3000 TL (\%34) ve 1000-2000 TL (\%32) gelir düzeyine sahip oldukları bilinmekte ve bu çoğunluğu oluşturan grubun alandaki ilk dikkat çeken ögeye vermiş olduğu cevaplar Şekil 2'de görüldüğü üzere grupların kendi içindeki yüzde oranlarına bakılarak sırasıyla alet çeşitliliği ve doğallık olduğu görülmektedir.

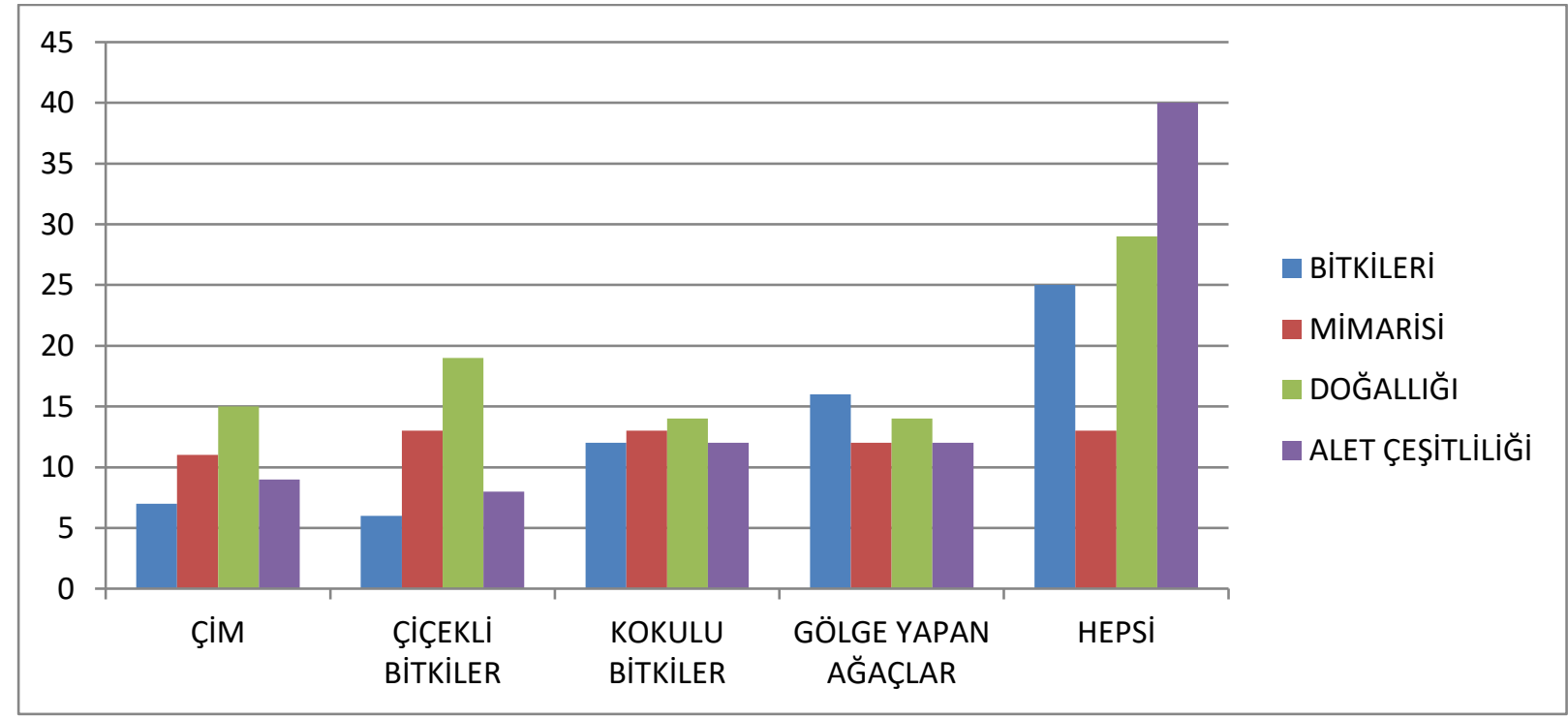

Şekil 3. Katılımcıların egzersiz yapılan alanda ilk dikkat çeken özelliği ile bu alanlarda hangi bitklerin olmasının istendiği arasında ki ilişki durumuna göre yapılan analiz sonuçları 
Dikkat çeken özellik sorusuna verilen cevaplara bakıldığında $\% 30$ oranla doğallık ve $\% 27$ oranla alet çeşitliliği verileri elde edilmiştir. Bu iki verinin bitki tercihlerine bakıldığında tüm bitkileri içeren hepsi cevabının yüksek olduğu görülmektedir.

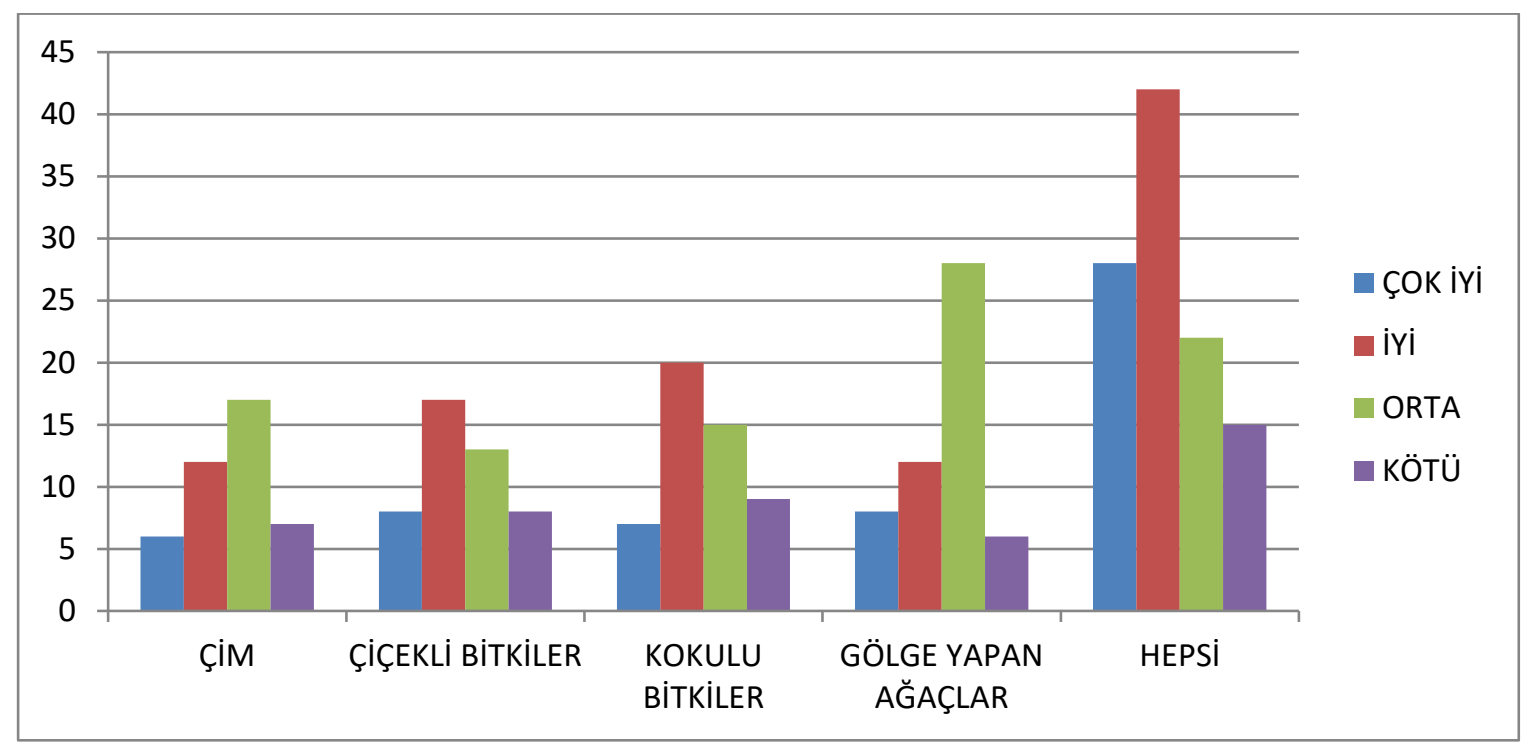

Şekil 4. Katılımcıların egzersiz yapılan alanın estetik açıdan değerlendirmesi ile bu alanlarda hangi bitklerin olmasının istendiği arasındaki ilişki durumuna göre yapılan analiz sonuçlar

Şekil 4'e bakıldığında alanda tüm bitkilerin kullanılması gerektğini düşünen kullanıcıların, alanı estetik olarak iyi tanımladığı anlaşılmaktadır. Açık yeşil alanlarda yer alan dış mekan spor aletlerinden bireylerin yararlandığ memnun oldukları görülmektedir. Ankete katılan halkın \%72'si bu uygulamadan memnun iken, \%28'i memnun olmadığını belirtmiştir. En fazla memnuniyet \%76 ile Beylikdüzün'de iken, en az memnuniyet \%34 ile Emirgan'da tespit edilmiştir.

\section{SONUÇ VE ÖNERILLER}

Rekreasyon kavramı gelişmiş ülkelerde gündemde olsa da gelişmekte olan ülkelerde henüz tam anlamıyla gündem olamamış bir konudur. İlerleyen yıllarda bunun devletler tarafindan önem kazanan bir konu olacağı ön görülmektedir. Çünkü ekonomik durum ve bunun getirdiği psikolojik ve fiziksel yükler çalışan insanların rahatlama, dinlenme ve eğlenme gibi ihtiyaçlarını daha da fazla artıracaktır. Aslında bu insani gereksinimlere sadece bireyin mental ve fiziksel sağlığı açısından bakılmamalı, çalışan bireyin daha verimli çalş̧abilmesi ve devlete ekonomik katk1 sağlaması boyutu da düşünülmelidir.

Yapılan bu çalışmanın bulguları incelendiğinde; özellikle yerel yönetimler 
açısından çeşitli öneriler ileri sürülebilir. Öncelikle yerel yönetimlerin yatırım planları yaparken rekreasyon konusunu daha fazla gözönünde bulundurmas1 gerekmektedir. Belediyelere ait park alanlarındaki sportif amaçlı aletlerin seçiminde bu konudaki uzman meslek disiplinleri ile işbirliği yapmaları buralardan yararlanan bireylerin sakatlik riskini azaltacağı ve toplumsal sağlığa katk1 sağlayacağı gözlemlenmiştir. Bunun yanı sıra toplumun ruhsal ve fiziksel sağlığını korumada büyük önem taşıan sportif rekreasyon faaliyetlerinin beklenen faydayı sağlaması için bilinçli bir biçimde yapılması gerekmektedir. $\mathrm{Bu}$ bilincin oluşabilmesi için alanında eğitim almış uzmanların öncülüğünde yapılması, hem sakatlıkların önüne geçilmesinde hem de kullanıcinın motivasyonunun artmasında yararı olacaktır. Belediyelerin bu alanları kullanan bireylere yönelik memnuniyet ve beklenti konusunda görüşlerini alabilecekleri çalışmalar planlamaları ve çalışmaların sonuçlarını dikkate almaları, halka hizmet vermek konusunda istekli oldukları mesajını vermelerini sağlayacaktır. Sadece alanların yapılması değil, bu alanların bakım, onarımının ve düzenlemelerinin yapılması, farklı zaman dilimlerinde denetlenmesi de verilen hizmet kalitesini artıracaktır (Yerlisu Lapa ve ark., 2012). Açık yeşil alanlarda kurulan bu aletler, kullanıciların kilo verme ya da kilosunu kontrol altında tutma, fiziksel görünüşünü iyileştirme ve sosyal imajını geliştirmek gibi dış görünüşe yönelik gerekçelerle kullanılmaktadır. Açık yeşil alanlarda spor yaparak; kendilerini daha mutlu, sağlıklı, güçlü ve rahatlamış hissetmektedirler. Kişilerin ruhsal ve fiziksel sağlığına katkıda bulunan bu etkinliklerden beklenen faydanın sağlanması için bir takım önlemlerin alınması gerekmektedir. $\mathrm{Bu}$ önlemler alındığında, mevcut açık yeşil alanlardaki spor aletlerinin daha doğru ve etkin bir şekilde kullanımı sağlanacaktır. Etkin ve verimli kullanılan açık yeşil alanların toplum sağlığına katkısı yanında insanların serbest zamanlarını daha verimli kullanımlarına da katkısı olacaktır. Günümüzde belediyeler oluşturdukları kentsel dönüşüm projeleriyle kentin dokusunu bozan yapıları yıkarak, insanları planlı yerleşim merkezlerine taşımaya çalışmaktadırlar. $\mathrm{Bu}$ süreçte İstanbul yeniden yapilanmakta, uygulanan toplu konut projeleriyle yeni yerleşim alanları kurulmakta ve eski alanlar ise rehabilite edilmektedir. Fakat rekreasyon sorununa henüz bir çözüm bulunulmamıştır. Gelişmiş 
ülkeler rekreasyon alanlarını da hesaba katarak yeni yerleşim merkezleri kurmaktadirlar. İstanbul'da ise yeni yerleşmeler oluşturulurken konutların yakın çevresine rekreasyon alanı olarak genellikle halkın rekreasyon gereksinimleri önemsenmeyerek küçük yeşil alanlar şeklinde oluşturulmaktadır. $\mathrm{Bu}$ durum rekreasyon alanları ile ilgili eski anlayışın devam ettiğini ve sorunun ileride de devam edeceğininin göstergesidir. Geniş ve kapsamlı bir planın olmaması şehrin artan rekreasyon ihtiyacına yerel yönetimlerin çözüm bulamamasının temel sonucudur. Yerel yönetimler açık rekreasyon alanlarını ve tesislerini gözardı ettikleri gibi, halkın rekreasyon alanları ile ilgili fikirlerini öğrenmek, rekreasyon davranışlarını ölçmek ya da kullanıcı gözüyle rekreasyon alanlarının problemlerini öğrenmek için de çalışmalar yapmamaktadır (Kara ve ark., 2008). Sonuç olarak İstanbul'un açık rekreasyon alanları mekansal değerlendirildiğinde rekreasyon alanlarının fiziksel olarak yetersiz olduğu, halkın taleplerini karşılayamadığı görülmektedir. Yerel yönetimlerin rekreasyon alanı konusunda uzman meslek disiplinleri ve kullanıcı grup ile iş birliği yaparak çalşılması gerekmektedir. Kullanıcın istekleri göz ardı edildiğinde alan aktif olarak kullanılamayacak, bireyler farklı yerlere hatta özel alanlara gitme ihtiyacı duyacaktır. $\mathrm{Bu}$ da yerel yönetimin halk tarafından sorgulanmasına sebep olacaktır.

\section{KAYNAKÇA}

Ardahan, F., Yerlisu-Lapa, T. 2011. Açık alan rekreasyonu: bisiklet kullanıcıları ve yürüyüşçülerin doğa sporu yapma nedenleri ve elde ettikleri faydalar. Uluslararası İnsan Bilimleri Dergisi, 8(1): 1303-5134.

Çerçi, S. 2012. Kamu alanlarının yaşam kalitesi üzerine etkisi ve Adana. Güney Mimarlık dergisi, Sayı:10, Aralık 2012.

Erdönmez, E., Akı, A. 2005. Açık kamusal kent mekanlarının toplum ilişkilerindeki etkileri. YTÜ Mimarlık eDergisi, 1(1).

Gül, A., Küçük, V. 2001. Kentsel açıkyeşil alanlar ve Isparta kenti örneğinde irdelenmesi. Süleyman Demirel Üniversitesi Orman Fakültesi Dergisi Seri: A(2): 27-48.

Kara, F. 2008. Şehir coğrafyası açısından bir araştırma: İstanbul'un açık rekreasyon alanlarının değerlendirilmesi. Marmara Coğrafya Dergisi, Sayı: 18:76-95.

Karaküçük, S. 1995. Rekreasyon boş zamanları değerlendirme kavram, kapsam ve bir araştırma. Ankara Gazi Üniversitesi Beden Eğitimi Spor Yüksekokulu. 
Koçan, N. 2007. Geleneksel ve önemi. Kentsel Peyzaj Alanlarının sporlarımızdan ciritin rekreasyon amacı ile Oluşumu ve Bakım Esasları Semineri 19 günümüze uyarlanması. Spor yönetimi ve May1s 2012, KONYA.

bilgi teknolojileri dergisi, 2(1):1306-4371.

Yerlisu Lapa, T. 2012. Belediye'ye ait

Melchert, L. 2005, The Dutch park alanlarını sportif amaçlı kullanan sustainable building policy: A model for developing countries. Building andEnviroment, 42 (2): 893-901. bireylerin katılımlarının ve beklentilerinin incelenmesi: Bornova örneği. I.

Önder, S., Polat, A.T. 2012. Kentsel Rekreasyon Araştırmaları Kongresi: 851865, 12 - 15 Nisan 2012, Kemer, Antalya. açık-yeşil alanların kent yaşamındaki yeri 